\title{
Mercados turísticos e desenvolvimento regional: a atuação dos agentes estatais de mercado na economia do turismo no Brasil.
}

\section{Tourist markets and regional development: the role of market-state actors in the tourism economy in Brazil.}

Elder P. Maia Alves ${ }^{1}$ e Wanderson Gomes ${ }^{2}$

Resumo: Este trabalho explora e analisa três frentes de interfaces entre o Estado brasileiro e os mercados turísticos nacionais, quais sejam: 1) o financiamento estatal-oficial das empresas que atuam diretamente nas atividades características do turismo (ACTs); 2) o processo de criação, disseminação e legitimação das políticas turísticas de médio e longo prazo (como o Plano Nacional de Turismo) e os marcos de regulação em torno das políticas regionais e locais de turismo; 3) o processo de construção publicitária, iconográfica e político-institucional dos destinos turístico e seus respectivos produtos de bem estar, prazer e fruição. Ao contrário do que sustenta as ortodoxias econômicas, muito ancoradas em suas defesas normativo-conceituais, a economia do turismo, no Brasil e outras latitudes, dependem inteiramente das ações estatais. A relevância dessas ações e o grau de interpenetração que instauram junto aos agentes empresariais, estabelecem um amálgama tão integrado que sustentamos ser muito mais fecundo, neste e em outros casos, tratar os agentes governamentais-estatais como agentes estatais de mercado (AEM). Com efeito, buscamos sustentar que os agentes estatais de mercado definem parte dos limites dos mercados turísticos no Brasil, assim como criam e difundem racionalidades empresariais e concorrem diretamente para a "mercadologização" dos territórios.

Palavras-chave: Economia do turismo; agentes estatais de mercado; financiamento; empresas do segmento turístico; construção dos destinos.

\footnotetext{
${ }^{1}$ Professor Adjunto do Instituto de Ciências Sociais e membro do Programa de Pós-Graduação em Sociologia da UFAL. E-mail: epmaia@hotmail.com.

2 Mestre em Sociologia pelo Programa de Pós-Graduação em Sociologia da UFAL. E-mail: wandersonjfgomes@hotmail.com.
}

Latitude, Vol. 9, no 2, pp. 343-379, 2015

DOI: https://doi.org/10.28998/2179-5428.20150206 
Mercados turísticos e desenvolvimento regional: a atuação dos agentes estatais de mercado na economia do turismo no Brasil.

\begin{abstract}
This paper explores and analyzes three fronts interfaces between the Brazilian state and national tourist markets, namely: 1) the state-official financing companies that act directly on the characteristics of tourism activities (ACTs); 2) the process of creation, dissemination and legitimation of tourist medium and long-term policies (such as the National Tourism Plan) and regulatory frameworks around the regional and local tourism policies; 3) the process of advertising construction, iconographic and political-institutional of tourist destinations and their well-being products, pleasure and enjoyment. Contrary to what sustains the economic orthodoxies, very anchored in its normative and conceptual defenses, the tourism economy in Brazil and other latitudes, entirely dependent on state actions. The relevance of these actions and the degree of interpenetration that establish with the business agents, establish an amalgam so integrated that we hold to be much more fruitful in this and other cases, treating the government-state actors as state agents Marketplace (AEM). Indeed, we seek to sustain that market-state actors define the limits of the tourist markets in Brazil, as well as create and disseminate business rationales and compete directly for "mercadologização" the territories.
\end{abstract}

Keywords: Economy of tourism; State agents market; financing; companies in the tourism sector; construction of destinations.

\title{
Introdução
}

Este trabalho explora três frentes de interfaces envolvendo o Estado e os mercados turísticos. A rigor, à luz de outros trabalhos já colimados ${ }^{3}$, essas interfaces autorizam a pensar que as ações estatais são decisivas para a própria organização, expansão e definição das estruturas dos mercados

\footnotetext{
${ }^{3}$ ALVES, Elder P. Maia. Cultura, mercado e desenvolvimento: a construção da agenda contemporânea para as políticas culturais. Revista Ciências Sociais UNISINOS, volume 50, no 3, p. 184 a 193, 2014.

ALVES, Elder P. Maia. As políticas econômico-culturais no (do) governo Dilma: o ValeCultura e a expansão do mercado editorial brasileiro. In: BARBALHO, Alexandre, RUBIM, Albino. CALABRE, Lia (Org).Políticas culturais no Governo Dilma. Salvador, EDUFBA, 2015.
} 
turísticos em países como o Brasil. Como assinalou Bourdieu (2015), uma das principais funções dos Estados contemporâneos é criar mercados. No caso dos mercados turísticos, mais do que criar os mercados e as suas regulações jurídicas, as ações estatais concorrem, em uníssono, não só para criar uma rede especifica de agentes privados (empresas e suas derivações), mas também para dotar esses próprios agentes privados de novas racionalidades empresariais, incentivando a inovação, o empreendedorismo e a competição. É o que faz, por exemplo, o Serviço Brasileiro de Apoio às Micro e Pequenas Empresas - SEBRAE. Em grande medida, foram as ações dos agentes estatais (governos, órgãos e empresas federais, estaduais e municipais) que contribuíram para a expansão do processo de turistificação (URRY, 1996), assim como para a construção de destinos turísticos específicos e a conversão desses destinos e seus territórios em produtos turísticos, urdidos para o deleite, a fruição e o prazer dos visitantes/turistas. Em uma palavra, as ações dos agentes estatais estão eivadas de um conjunto de terminologias, técnicas de planejamento e elaboração de produtos turísticos que as tornam muito semelhantes às práticas de racionalização empresarial levadas a cabo pelas empresas e os agentes privados. Ora, nesses termos, parece inteiramente contraproducente falar em Estado e mercados turísticos ou em políticas turísticas oficiais e economia do turismo, sugerindo que um e outro mantêm limites definidos e/ou áreas de atuação previamente prescritas. Com efeito, buscando traduzir os diversos feixes de interdependências e complementariedades existentes nessa figuração Estado/mercado turístico, sustentamos que é muito mais fecundo capturar essas relações contemporâneas a partir da categoria de agentes estatais de mercado (AEM). A construção dessa categoria é, em grande medida, tributária dos esforços de pesquisa $^{4}$ realizados para compreender a figuração mercados culturais/Estado no Brasil contemporâneo. Por sua vez, essa agenda de pesquisa segue de perto as pistas teóricas construídas por Norbert Elias.

${ }^{4}$ O BNDES e a economia criativa: o financiamento das empresas culturais brasileiras. In: Economia criativa: heranças, inovações e perspectivas. GARCIA, Sandro (Org.). Porto Alegre, UFRGS, 2016.

As políticas econômico-culturais no (do) Governo Dilma: o Vale Cultura e a expansão do mercado editorial brasileiro. In: Políticas culturais no governo Dilma. BARBALHO, Alexandre (Org.). Salvador, 2015, Edufba. 
Mercados turísticos e desenvolvimento regional: a atuação dos agentes estatais de mercado na economia do turismo no Brasil.

Ao sugerir a adoção dessa categoria não sustentamos, de modo algum, que a economia do turismo ou os mercados turísticos integram ou dinamizam a retomada de um suposto capitalismo de estado. Essa categoria não traduz com fidedignidade as redes e tramas minuciosas e complexas existentes entre as ações político-governamentais e a formação de interesses convergentes, que envolve uma malha de empresas privadas (sobretudo grandes empresas) em torno do turismo. A categoria de capitalismo de Estado ${ }^{5}$, quando muito, foi utilizada para tratar - em países como o Brasil - da relevância assumida pelas empresas estatais, notadamente aquelas que atuaram, no decurso das décadas dos anos 70 e 80 do século passado, nos ramos de energia, mineração e infraestrutura. No âmbito da economia de serviços, onde o turismo pulsa forte e de modo muito complexo, não é possível mobilizar essa categoria para analisar e explicar a figuração estado/mercados turísticos. Com efeito, também não é fecundo lançar mão da classificação industrial para se referir aos bens, serviços, produtos e atividades ofertados pelas empresas de turismo, uma vez que, na maioria dos casos, as empresas que atuam no segmento do turismo são empresas de serviços, que ofertam serviços de alimentação, transporte, lazer, cultura e bem estar; logo, serviços mais próximos da construção de experiências e sensações, distantes da dimensão industrialfuncional. Nesse sentido, soa inócuo falar em indústria do turismo.

São muitas as relações entre os agentes estatais de mercado (AEM) e os demais agentes que operam no interior da economia do turismo e dos mercados turísticos, assim como ocorrem de diferentes formas, desde a ação de bancos oficiais, passando por agências regionais de desenvolvimento, universidades e governos municipais. Ao invés de tratar cada um desses agentes em seus diferentes contextos político-institucionais - o que não seria possível na extensão deste espaço - , optamos por tratar de três diferentes interfaces que evidenciam os atravessamentos estruturais e recorrentes entre Estado e mercado, são elas: 1) o financiamento das

${ }^{5}$ A categoria capitalismo de Estado foi cunhada nos anos 60, no âmbito da CEPAL. Muitos pesquisadores, notadamente da economia, passaram a utilizá-la nos anos 80 e 90 para interpretar a dinâmica das transformações econômica de muitos países ao redor do mundo. Todavia, a gênese empírica da relação entre empresas estatais (participação acionária total do Estado) e mercado, remonta aos anos 20 e 30, com o advento dos Estados corporativos totalitários europeus, e alguns estados latinoamericanos, como, por exemplo, o Brasil da primeira era Vargas. 
empresas privadas que atuam no interior do segmento de turismo; 2) a definição de políticas, planos de estruturação e racionalização geral das normas e legislação sobre o turismo; 3) a construção simbólico-publicitária dos destinos regionais e locais, a partir de suas diversas materialidades, infraestruturas e consecução dos equipamentos de entretenimento, lazer, cultura e diversão. Essas três frentes de interfaces ocorrem hoje de modo sincrônico, tendo cada uma rebatimentos sobre as demais. Com efeito, o trabalho que se segue esposa um forte pendor descritivo, na medida em que pretende evidenciar essas interpenetrações e singularidades. Nessas três frentes, os agentes estatais de mercado (AEM) sofrem as pressões decorrentes dos interesses dos principais agentes privados de mercado, as empresas, notadamente das grandes redes hoteleiras, companhias aéreas, agências de viagens e entidades sindicatos patronais ligados aos setores de comércio e varejo. Isso não significa, todavia, que os conceitos criados, os índices de aferição de competitividade, os marcos regulatórios e as técnicas de planejamento desenvolvidas, sejam diretamente tributários dos interesses privados. Tanto os agentes estatais quanto os agentes privados mantém, nesse seara, interesses convergentes e complementares, que circulam e se retroalimentam. As três frentes de interfaces descritas não ocorrem da mesma maneira pais afora, abrigando características muito específicas nos contextos político-institucionais. Por exemplo, no caso da terceira frente, a construção dos destinos turísticos, os agentes estatais e governamentais locais são decisivos, são eles os responsáveis pela construção das sinergias e as narrativas imagético-publicitárias em torno dos locais, dos lugares, dos territórios e, portanto, do fluxo de fantasia e encantamento idílico de que esses espaços devem ser revestidos.

Os mercados turísticos são figurações complexas, interdependentes, assimétricas e mundializadas. Abrigam graus variados de conexões e redes empresariais, tecnológicas e processos de inovação, possuindo também distintos fluxos econômicos, simbólicos, publicitários e políticos. Em conjunto, dão vida a um dos elos mais vibrantes e decisivos da economia contemporânea de serviços. Segundo a Organização Mundial do Turismo (OMT), órgão do sistema das Nações Unidas (ONU), o turismo corresponde a $12 \%$ do Produto Interno Bruto (PIB) global (superando qualquer outro segmento), pondo em circulação anual cerca de 900 milhões de turistas internacionais. Em linhas gerais, a expansão das práticas turísticas e o recrudescimento das viagens nos últimos 30 anos, deriva da 
Mercados turísticos e desenvolvimento regional: a atuação dos agentes estatais de mercado na economia do turismo no Brasil.

transformação do padrão de bem estar global, que se fez acompanhar da ascensão das classes médias urbanas dos países em desenvolvimento nos últimos anos, notadamente China, Rússia e Brasil. No caso deste último, conforme Souza (2009) e Pochmann (2014), a mobilidade constatada se refere muito mais à ascensão dos novos contingentes de trabalhadores urbanos e rurais, que, com efeito, passaram a ter acesso a novos bens e serviços, entre eles os produtos turísticos.

De modo geral, os mercados turísticos estão organizados a partir de cinco grandes dimensões. São elas: 1) as empresas privadas, divididas em pequenas, médias e grandes organizações, que, direta ou indiretamente, auferem parte dos seus lucros a partir da venda de serviços e bens em regiões com forte fluxo de turistas, que atuam especialmente nos setores de alimentação, transporte, entretenimento, lazer e cultura; 2) os trabalhadores do turismo, que estão divididos em muitas clivagens (atribuições e competências; média de renda; natureza da atividade; etc.), que envolve desde os serviços domésticos (limpeza de quartos de hotéis) até os serviços de tradução e guia; 3) a atuação dos diferentes órgãos e estruturas governamentais na construção dos destinos, sejam aqueles mais convencionais, como os destinos de sol e praia, sejam os mais insólitos, como a visita às comunidades pobres das periferias das grandes metrópoles latino-americanas; 4 ) as instituições (públicas e privadas) responsáveis pelo treinamento e capacitação das competências e mão de obra especializadas (garçons, tradutores, camareiras, atendentes, agentes de viagens, guias, motoristas, etc.); 5) bancos públicos e privados, responsáveis pelo financiamento de grandes projetos de infraestrutura privada (financiamento de empresas de hotéis, redes de resorts e centros de lazer) e/ou infraestrutura pública (sítios históricos, mercados municipais, estradas, ruas, espaços culturais, entre muitos outros). Sem a presença de uma dessas dimensões ou eixo, se compromete a compreensão da dinâmica socioeconômica desses mercados.

O serviço central que anima a economia do turismo, e que faz dela uma das frentes mais dinâmicas e competitivas do capitalismo contemporâneo, diz respeito à construção das tecnologias de fruição, prazer e bem estar. No seio da intrincada rede de novas racionalidades econômicas que Lipovetsky e Serroy nomearam de capitalismo artista ou capitalismo criativo transestético, o turismo condensa o que os contingentes de consumidores mais desejam e projetam para si: a experiência de viverem 
novas sensações, descobertas estéticas, vibrações, emoções, expressões e fantasias. Essas demandas intersubjetivas estão presentes nos mais diferentes mercados turísticos, escalas, territórios e regiões, assim como as diversas clivagens de segmentos turísticos: turismo de aventura; turismo litorâneo; turismo cultural; turismo ambiental; turismo religioso, entre muitos outros. Como assinalam Lipovetsky e Serroy, em todo o mundo, a cada 5 anos, cresce em $10 \%$ o número de museus - destaque-se que este é um equipamento turístico-cultural que exige grande planejamento, pesquisa, curadoria, investimentos urbano-arquitetônicos, aquisição de acervo, definição de perfil conceitual-museal e liberação de financiamento. Logo, trata-se de um equipamento que demanda mais tempo de construção, instalação e uso do que os demais. Em países como a França, o número de festivais, exposições e espetáculo cresceu substancialmente nos últimos 20 anos, passando de 2000 anuais. Somente em 2008, foram contabilizados mais de 70 milhões de ingressos vendidos para os principais equipamentos turísticos e culturais de Paris, com destaque para o Louvre (8,8 milhões de visitantes); o Castelo de Versalhes (6,5 milhões) e o Centro Cultural Jorge Pompidou (3,6 milhões).

No Brasil, salta aos olhos a expansão da rede de museus e cetros culturais urbanos, especialmente no eixo Rio-São Paulo. O primeiro, por meio de equipamentos culturais urbanos como o Centro Cultural Banco do Brasil (CCBB), tem liderado, em âmbito global, o número de visitantes a exposições públicas. Em 2014, a exposição sobre o pintor espanhol Salvador Dalí foi a exposição pública mais visitada do mundo, recebendo mais de um milhão de frequentadores. Recentemente, outro grande museu foi inaugurado no centro do novo perímetro urbano delineado e instaurado no centro do Rio de Janeiro, o Museu do Amanhã, projetado pelo arquiteto espanhol Santiago Calatrava (um dos arquitetos-marca, autor de diversos projetos arrojados em todo o mundo). O Museu do Amanhã se inscreve como a principal ancora cultural do projeto urbano-imobiliário Porto Maravilha, que abarca toda a Zona Portuária do Rio de Janeiro. A rede de museus de cidades como o Rio de Janeiro, Paris e Nova York definem uma nova economia política das cidades, no interior da qual os espaços urbanoculturais projetam e ofertam as suas diferentes mercadorias estéticas, tornando a cidade um bem de consumo simbólico-cultural da experiência cotidiana dos moradores e nativos e extra cotidiana dos visitantes e turistas. 
Mercados turísticos e desenvolvimento regional: a atuação dos agentes estatais de mercado na economia do turismo no Brasil.

$\mathrm{Na}$ França e em diversos outros lugares do mundo, esse contingente de consumidores das cidades e as suas mercadorias estéticas, das tecnologias de prazer, da emoção, da excitação e da fantasia, dinamizam uma miríade de outros serviços, aqueles que correspondem ao maior patamar de gastos e integram as chamadas atividades características do turismo (ACTs), como transporte, alimentação e hospedagem. Essa verdadeira engrenagem de oferta de bens de fruição, prazer e bem estar não seria possível sem a atuação dos agentes estatais - órgãos de planejamento, execução, deliberação, financiamento e qualificação profissionais ligados aos governos centrais dos principais países receptores e emissores de turistas. A atuação desses agentes estatais nem sempre se faz acompanhar da melhoria das condições de vida das populações das cidades, lugares e regiões que mais recebem os contingentes de turistas. Antes o contrário, em muitas ocasiões a atuação de tais agentes acentua as assimetrias regionais, locais e, por conseguinte, recrudescem as desigualdades socioeconômicas. Todavia, a pujança desses mercados não assumiria a relevância econômica global se esses agentes não participassem diretamente da construção dessa complexa rede de oferta de bens de bem estar e prazer. O fazem de diversas formas, atuando desde o financiamento direto destinado à construção e recuperação de equipamentos turísticos convencionais (como hotéis e infraestrutura - estradas, aeroportos e saneamento); passando pelo investimento em equipamentos turísticos urbanos, responsáveis pela formação das ancoras de visitação (museus, teatros, bairros, balneários, sítios histórico-arquitetônicos, etc.), que carecem de mais tempo e planejamento; passando também pela normatização e definição de planos estratégicos (como o Plano Nacional de Turismo); até a construção especifica de cada destino, algo que envolve um trabalho complexo e interinstitucional de valorização de determinados atributos (comida, paisagem, manifestações artísticas, sítios urbanos, artesanatos, atributos naturais, entre outros), que exige o financiamento, em médio prazo, em publicidade, marketing e toda sorte de recursos iconográficos, simbólicos e imateriais, no interior dos quais são criados os chamados produtos turísticos. Em uma palavra, sem os agentes estatais não seria possível a profusão do processo de turistificação dos lugares e territórios

No interior dos mercados turísticos, os agentes estatais têm um papel decisivo. Não se trata apenas de construir políticas de turismo e 
desenvolvimento, os dados disponíveis, as discussões realizadas e o teor das ações empreendidas revelam que os agentes estatais, em grande medida, constroem os próprios mercados, pois são os principais responsáveis pela construção e coordenação geral da oferta dos serviços, do bem estar e dos bens de prazer que animam a economia do turismo. Justamente por isso, sustentamos que os agentes estatais diretamente implicados nas tramas dessa economia devem ser empiricamente tratados como agentes estatais de mercado (AEM).

A atuação financeira dos agentes estatais de mercado junto às empresas privadas.

A primeira interface envolvendo a figuração Estado/mercados turísticos concerne ao financiamento direto das empresas que atuam nas ACTs - Atividades Características do Turismo, notadamente as médias e grandes empresas. Segundo material lançado pelo Ministério do Turismo brasileiro em parceria com o Centro de Gestão e Estudos Estratégicos $(\mathrm{CGEE})^{6}$, o turismo é atualmente a atividade que mais gera emprego e renda em todo o mundo, atingindo a marca de mais de 203 milhões de postos, ou $8 \%$ do total global; contribui com três trilhões de dólares para a economia mundial, ou $11 \%$ do total; responde por 603 bilhões em investimentos, ou $9 \%$ do total. Todos os dados apontam tendências de crescimento, mas já corroboram as expectativas dos intelectuais que acompanham de perto o início desse processo, ao afirmarem que os números surpreendiam. Segundo dados da própria Organização Mundial do Turismo (OMT), as chegadas de turistas internacionais (visitantes que pernoitam) cresceram $4 \%$ em 2012, superando pela primeira vez em sua história a marca de um trilhão de turistas (995 bilhões no ano anterior). Para o World Travel \& Tourism Council, a estimativa é que até o ano de 2022 o turismo seja responsável por 3,63 milhões de empregos, só no Brasil, incluídas nesses dados de empregos diretos atividades relacionadas a hotelaria, agências de viagens, companhias aéreas, outros tipos de transportes de passageiros, restaurantes, lazer. $\mathrm{O}$ gráfico seguinte ilustra $\mathrm{o}$ crescimento num intervalo de apenas 12 anos, em se tratando do fluxo

${ }^{6}$ Estudos da Competitividade do Turismo Brasileiro - Ministério do Turismo (2007). 
Mercados turísticos e desenvolvimento regional: a atuação dos agentes estatais de mercado na economia do turismo no Brasil.

internacional. De acordo com o gráfico 1, o crescimento do setor do turismo foi constante, sendo apenas os anos de 2003 e 2009 representados como os mais atípicos na lógica de crescimento. Esse desenvolvimento acompanhou a evolução da economia global mas, mesmo com as últimas instabilidades econômicas, sobretudo pelo segmento imobiliário dos Estados Unidos e países europeus, continuou surpreendentemente em elevação.

\section{Gráfico 1 - Comportamento do fluxo turístico internacional.}

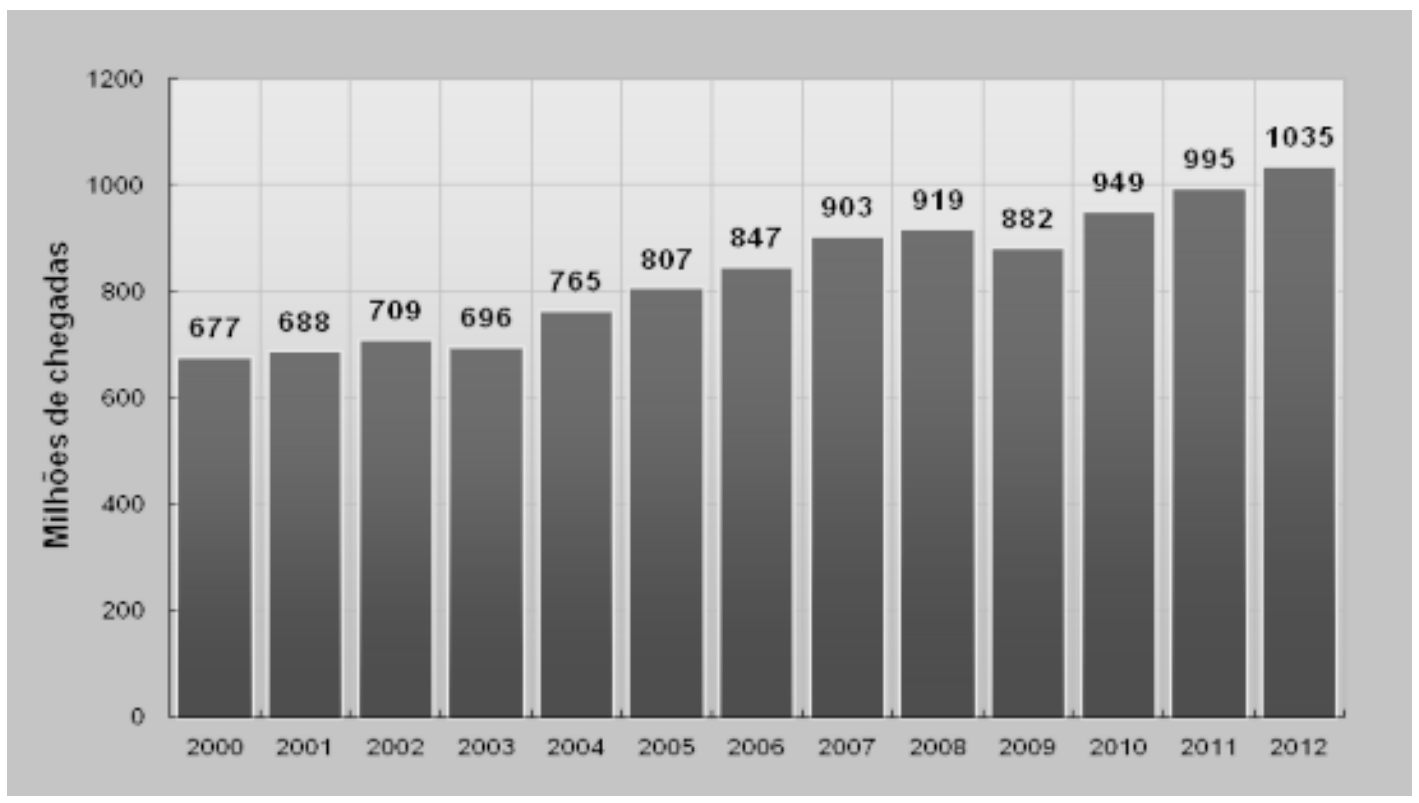

Fonte: Organização Mundial do Turismo (OMT).

No gráfico 1, notamos, de modo geral, uma correlação positiva entre turismo e economia global, o que tem marcado as características de crescimento de ambos. Os anos de 2003 e 2004 foram anos atípicos, onde o turismo recuou em seu crescimento contra um leve crescimento da economia global em 2003. Um segundo gráfico nos mostra o desempenho do turismo frente a economia global num intervalo de 12 anos. Os dados são recentes. Evoluíram com base em um nível de planejamento que muito ultrapassou a perplexidade dos governos com o setor em períodos mais germinais. Mas a partir da década de 1970, os números também já eram crescentes e igualmente marcantes. No início da década de 1980, os 
números de deslocamentos dos turistas em escala mundial já ultrapassavam a marca de 300 milhões e o turismo internacional era o segundo maior item do comércio mundial (URRY, 1996). Com a importância do setor e as consequentes transformações que ocasionaria, seria necessário uma organização igualmente ampla, para buscar orientar o processo, como foi alcançado com a Organização Mundial do Turismo (OMT).

No Brasil, de acordo com os dados do Conselho Mundial de Viagens e Turismo, o setor, que recebeu mais de $\mathrm{R} \$ 13,5$ bilhões em financiamento de instituições federais, tem contribuído atualmente com cerca de $9,2 \%$ do PIB, equivalente a $\mathrm{R} \$ 443,7$ bilhões, colocando o país na sexta posição mundial, e com ampla perspectiva de crescimento. Segundo informa a plataforma virtual do Ministério do Turismo brasileiro ${ }^{7}$, a pesquisa que apresenta os referentes dados foi realizada com os maiores empresários da área e coleta informações em 184 países. No Brasil, especialmente na região Nordeste, os financiamentos a longo prazo passaram a vigorar após 1970, no apogeu das políticas que visavam o desenvolvimento regional do país, uma das características da acentuada preocupação do governo federal com as assimetrias socioeconômicas interregionais. Nesse sentido, financiamentos e incentivos fiscais passaram a ser realizados por instituições especializadas, como a EMBRATUR (Instituto Brasileiro de Turismo), FINAME (Agência Especial de Financiamento Industrial), SUDENE (Superintendência de Desenvolvimento do Nordeste) e SUDAM (Superintendência de Desenvolvimento da Amazônia), para o provimento de reparos, ampliação, aprimoramentos e construção de hotéis que incentivassem uma estadia prolongada e de qualidade aos turistas dos mais variados lugares do mundo, oportunizando, assim, o engajamento regional na dinâmica de crescimento nacional. Vantagens fiscais e redução de alguns impostos começaram a ser oferecidos aos investidores por Estados e prefeituras, algo que estimulou a implantação de redes hoteleiras nacionais e internacionais em larga escala.

Uma das principais mudanças realizadas após a atuação do Ministério do Turismo, criado em 2003, se refere ao processo de captação de recursos financeiros, que já foi percebida logo nos primeiros meses sob os novos parâmetros, quando foram articuladas linhas especiais para o

${ }^{7}$ Ministério do Turismo (2014). http://www.turismo.gov.br/ 
Mercados turísticos e desenvolvimento regional: a atuação dos agentes estatais de mercado na economia do turismo no Brasil.

turismo com instituições financeiras específicas. Segundo apresenta o Relatório do Plano Nacional de Turismo, de 2003, os Ministérios do Turismo, Trabalho e Emprego e da Integração Nacional, foram feitas dotações orçamentárias junto ao Banco do Brasil e a Caixa Econômica Federal no montante de $\mathrm{R} \$ 1,4$ bilhão para serem investidos no setor do turismo nos doze meses seguintes, distribuídos entre infraestrutura e serviços. Ainda segundo dados divulgados pelo próprio Ministério do Turismo, em 2007, entre os anos de 2003 e 2006 os financiamentos dos bancos públicos federais ao setor de turismo atingiram um crescimento de $26 \%$ ao ano. Nessa frente de desembolso e financiamento direto às empresas que atuam no mercado turístico (redes hoteleiras, construtoras, agências de viagens, companhias aéreas, agências publicitárias, empresas de transporte, entre outras) as instituições financeiras federais cumpriram um papel decisivo. Os bancos federais como o Banco Nacional do Desenvolvimento Econômico e Social (BNDES), o Banco do Brasil S/A (BB), a Caixa Econômica Federal (CAIXA), o Banco da Amazônia (BASA) e o Banco do Nordeste (BNB) concorreram substancialmente para a elevação do volume de crédito para o setor turístico nos últimos anos. Entre 2003 e 2013 ocorreu um crescimento de $923,60 \%$ no financiamento direto às atividades características do turismo (ACTs). Apenas em 2012, o valor dos financiamentos direcionados pelas instituições financeiras federais alcançaram a marca de $\mathrm{R} \$ 11,2$ bilhões, significativo aumento de $30 \%$ se comparado ao ano anterior. Dados mais recentes apresentados pelo portal do Ministério do Turismo atestam que ocorreu um aumento exponencial no financiamento ao segmento, que soma, entre 2003 e 2014, o valor de $R \$ 78,2$ bilhões. A maioria desses recursos foi utilizada na forma de empréstimos a empresas privadas para a construção e reforma de hotéis, bares, restaurantes, parques temáticos e centros de entretenimento, etc. 


\section{Gráfico 2 - Financiamento para o turismo realizado por instituições financeiras federais (R\$ bilhões).}

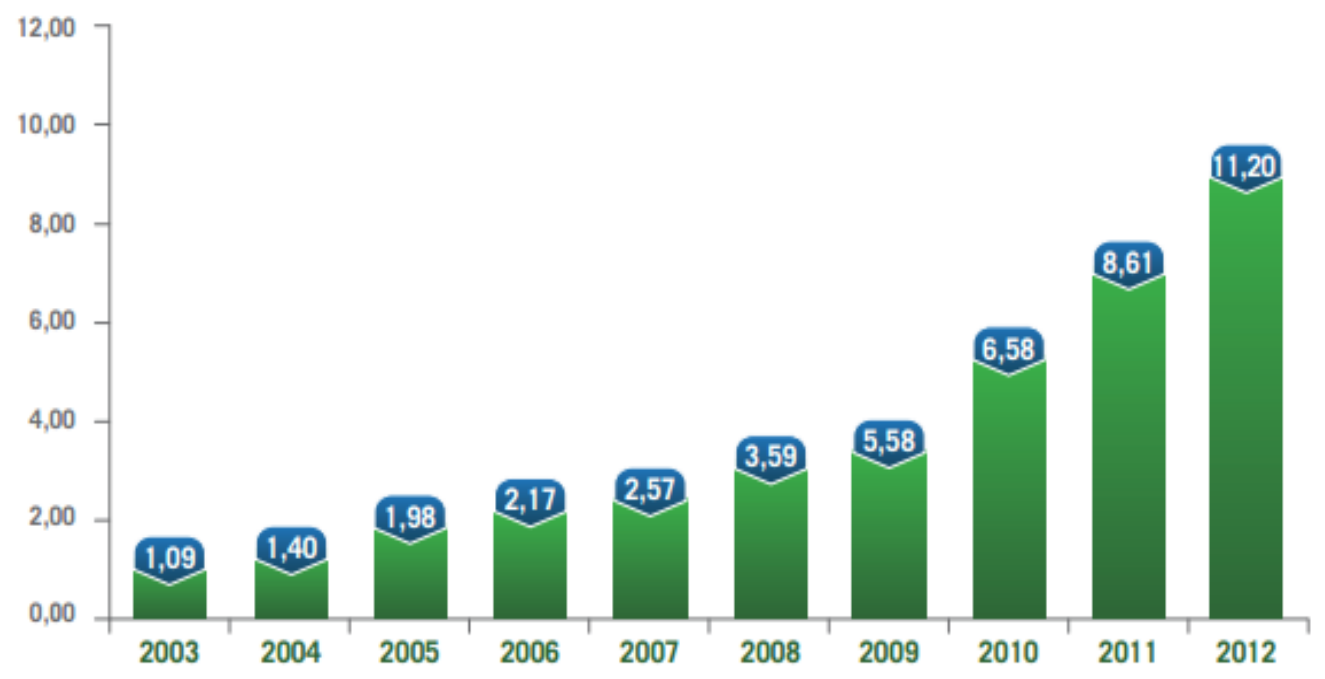

Fonte: Ministério do Turismo (MTUR), 2012.

Não figura nesse computo (evidenciado pelo gráfico 1) os recursos repassados por órgãos federais (como o Ministério do Turismo, o Ministério das Cidades e o IPHAN - Instituto do Patrimônio Histórico e Artístico Nacional) para as prefeituras, fundações municipais e governos estaduais destinados à requalificação urbana e construção de equipamentos turísticos e culturais públicos. A esse respeito, salta aos olhos, por exemplo, os recursos destinados pelo Programa PAC das Cidades Históricas. Criado em 2013, no âmbito da segunda fase do Programa de Aceleração do Crescimento (PAC), o Ministério do Planejamento, Orçamento e Gestão (MPOG) autorizou a criação de uma linha de ação destinada exclusivamente à revitalização e requalificação dos sítios históricos sob a alçada do IPHAN. Desde então, foram aprovados ações para a requalificação de 425 obras em edifícios, instalações e espaços públicos, espraiados por 44 cidades e 20 Estados da federação, com valor total de R\$ 1,640 bilhão. Desse total, a região Nordeste foi a que obteve o maior percentual de recursos, aproximadamente $43 \%$ ( $\$ 725$ milhões); seguida da região Sudeste, com aproximadamente 33\% (cerca de $\mathrm{R} \$ 541$ milhões).

Os financiamentos ao setor de turismo no Brasil, liderados pelos bancos públicos, alcançaram o montante de $\mathrm{R} \$ 899$ milhões apenas em junho de 2015, melhor marca do ano (mas fechando ainda abaixo dos $\mathrm{R} \$ 1,1$ 
Mercados turísticos e desenvolvimento regional: a atuação dos agentes estatais de mercado na economia do turismo no Brasil.

bilhão do ano de 2014 no mesmo mês, muito em decorrência dos investimentos para operacionalização da Copa do Mundo de Futebol FIFA, como formação de equipes de apoio, revitalização e sinalização turística). O valor referido em 2015 diz respeito ao crédito disponibilizado pelo Banco do Brasil, Caixa Econômica Federal, Banco Nacional do Desenvolvimento Econômico e Social, Banco da Amazônia e Banco do Nordeste, aumentando em $34 \%$ se comparado ao mês de janeiro do mesmo ano, no qual foi realizado o desembolso de $\mathrm{R} \$ 670$ milhões. Caixa Econômica Federal e Banco do Brasil lideram entre as instituições financeiras que mais emprestam dinheiro para as empresas privadas que atuam no setor, com $52 \%$ e $37 \%$, respectivamente.

Gráfico 3 - Bancos e financiamentos para o turismo - 2007.

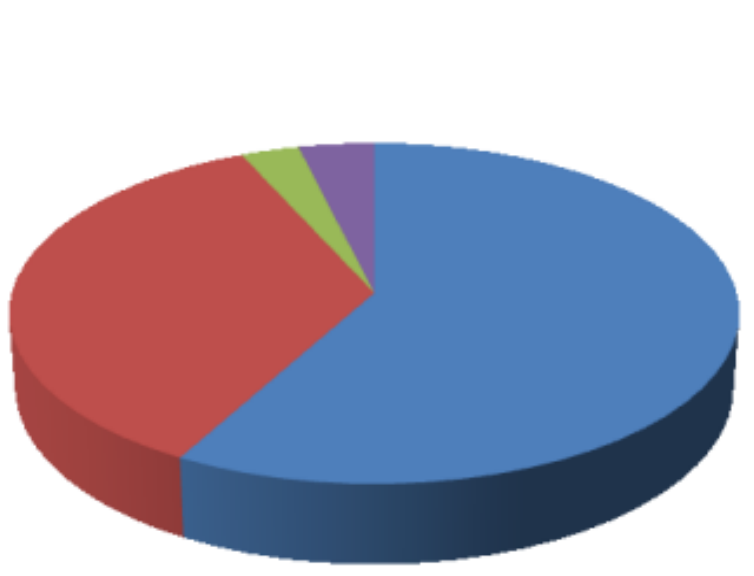

\section{Banco do Brasil}

n Caixa Econômica Federal

Banco Nacional de

Desenvolvimento

Econômico e Social BNDES

Banco do Nordeste

Fonte: BC - 2007

Foi em 1970 que os financiamentos a longo prazo começaram a vigorar, através da própria EMBRATUR, FINAME, etc., ou mesmo, por parte dos incentivos fiscais, como a SUDENE (Superintendência de Desenvolvimento do Nordeste) e SUDAM (Superintendência de Desenvolvimento da Amazônia), para reparos, ampliação e construção de hotéis que incentivassem a estadia de turistas de diversos lugares do mundo e que possibilitassem, assim, o engajamento de suas regiões no crescimento nacional. Vantagens fiscais e redução de alguns impostos 
passaram a ser oferecidas aos investidores por Estados e prefeituras, que estimulou o desenvolvimento das redes hoteleiras nacionais (que praticamente dobrou sua capacidade de hospedagem) e internacionais. Nesse período, importantes cadeias nacionais foram criadas, como Othon, Eldorado, Horsa, Hotel Nacional Rio e a rede Tropical de Hotéis. Em 1975, a primeira cadeia hoteleira internacional se instalou em São Paulo com mais de 400 apartamentos, a Hilton ${ }^{8}$. Percebendo essa vertente de negociações das redes hoteleiras que passavam a conferir êxito aos empreendimentos cada vez mais amplos e diversificados, a EMBRATUR também buscou oferecer orientação ao processo, elaborando o intitulado Regulamento Geral para Classificação dos Meios de Hospedagem Brasileiros, no intuito da classificação e ordenamento desse subsetor para um maior controle no investimento de incentivos fiscais e um uso mais consciente de seus benefícios. Mas não se tratava apenas de hotéis. Ao longo do tempo e uma delimitação mais objetiva dos gostos do turista visitante, redes públicas começaram a perceber que restaurações eram necessárias. O "olhar romântico" do turista foi desde cedo despertado pela busca em vivenciar elementos do passado como, por exemplo, formas rústicas e manuais do trabalho no campo e a vida em todos os seus aspectos. Por isso, houve uma busca posterior de restauração e preservação de locais históricos em ruínas. Urry (1996) destaca a importância da ação de instituições públicas para a preservação, principalmente com base nas experiências que conduziram sua pesquisa e nas análises da ampliação, restauração e preservação dos museus na Grã-Bretanha.

Há um elenco variado de empresas do seguimento turístico que obtém empréstimos junto aos bancos públicos oficiais. Entre elas, há, sem dúvida, destaque para as agências e operadoras de viagens. Em 2012 as operadoras e agências de viagens transportaram 6,3 milhões de turistas. (Associação Brasileira de Operadoras de Turismo, BRAZTOA). As viagens domésticas apresentaram 4,3 milhões de turistas transportados, a partir de um valor médio de $\mathrm{R} \$ 1.148,00$ por turista. As viagens internacionais atingiram o número de 1,7 milhões de turistas transportados, com valor médio de $\mathrm{R} \$ 2.667,00$ por turista. Para o Brasil, os gastos dos turistas com o

\footnotetext{
${ }^{8}$ Mas, essas condições não excluíram a possibilidade de aumento dos chamados "meios de hospedagem alternativos", como albergues, campings e residências secundárias.
} 
Mercados turísticos e desenvolvimento regional: a atuação dos agentes estatais de mercado na economia do turismo no Brasil.

transporte representou um faturamento de 9,84 bilhões em 2011. Em 2012, houve um crescimento de $8 \%$, com um faturamento de 10,3 bilhões. A trajetória da empresa CVC (maior agência de turismo das Américas) expressa bem esse crescimento. Desde o início do século a empresa vem alcançando índices acentuados de crescimento; em 2012 passou a ser uma das poucas operadoras de viagens do mundo a negociar suas ações na bolsa de valores, tornando-se a CVC Brasil Operadora e Agência de Viagens S.A. (BM\&FBOVESPA: CVCB3). No primeiro semestre de 2015, a empresa obteve um crescimento de $12 \%$ em comparação com o ano anterior, alcançando um total de $\mathrm{R} \$ 2,5$ milhões em reservas confirmadas.

Para o Brasil, operadoras e agências de viagem estão inseridas na proposta de profissionalização dos serviços com o turismo, desde a criação do Ministério do Turismo. São representadas nos Estudos de Competitividade do Turismo Brasileiro, parceria entre MTUR e Centro de Gestão e Estudos Estratégicos (CGEE), como organizações comerciais que atuam junto ao consumidor e ao próprio agente de viagem (operadoras) e empresas organizadas que são intermediárias de produtos turísticos, permitindo uma maior conciliação entre demanda e oferta (agências de viagem). A mudança de postura governamental quanto aos processos administrativos do turismo sugere, logicamente, uma atualização das operadoras e agências de viagem. Com o advento dos megaeventos, as demandas serão cada vez mais extensas e difíceis de serem sanadas com serviços de baixa qualidade. Em 2005, a ABAV indicava que o segmento empregava mais de 35 mil profissionais diretos e mais 100 mil indiretos. As viagens de negócio, destacadas por Sanovicz (2007) como uma das mais novas prioridades de governo, chegaram a representar o terceiro maior gasto das empresas brasileiras, movimentando cerca de 10 bilhões anuais, equivalente a $67 \%$ do turismo nacional. (Associação Brasileira de Gestores e Viagens Corporativas).

Justificando a expansão do turismo nacional e sua participação cada vez mais decisiva na economia do país, o Plano Nacional de Turismo (2013-2016) elenca uma série de indicadores, dentre os quais está o crescimento do volume de crédito destinado ao setor, para explicar suas pretensões: a de colocar o Brasil entre as três maiores economias turísticas do mundo até o ano de 2022. Quanto aos empregos gerados pela economia turística no Brasil, em sua totalidade, a região Sudeste responde por 56\% das ocupações formais (com 965.007 empregos formais). Nordeste, Sul, 
Centro-Oeste e Norte aparecem com $17 \%, 16 \%, 8 \%$ e $4 \%$, respectivamente. Segundo o World Travel \& Tourism Council (WTTC), em dados divulgados em 2011, o setor do turismo brasileiro ocupava a $6^{\mathbf{a}}$ posição entre os principais países geradores de renda. A mesma instituição previa um crescimento de apenas uma posição até 2022. O Plano destaca o crescimento avassalador do setor pelo mundo, ao indicar dez países que mais aumentaram suas receitas a partir do turismo, como: Japão $(37,0 \%)$; Índia e África do Sul (22,0\%); Suécia e República da Coréia (19,0\%); Tailândia (18,0\%); China (Hong Kong) e Polônia (16,0\%); Estados Unidos (10\%); Reino Unido (6,0\%) e Alemanha (5,0\%). (Organização Mundial do Turismo, 2013). China e Rússia, destaca o material, foram os destinos emissores que demonstraram maior crescimento no exterior $(42,0 \%$ e $31,0 \%$, respectivamente). A relevância ainda se configura quando, apesar da retração econômica dos Estados Unidos e da Zona do Euro em 2012, um crescimento médio de 3,9\% do transporte de passageiros (domésticos e internacionais) é identificado, se comparado ao ano de 2011 (2,8\% para o transporte doméstico e 5,3\% para o transporte internacional, segundo dados Airports Council International, 2013).

No Brasil, no que toca à captação de recursos, tanto públicos como privados, o Estado da Bahia vem liderando historicamente o Nordeste. Prova disso é que, com a ampliação do conceito de "resort"9 no Brasil, houve, sobretudo no final do século $X X$, um processo irrefreável de multiplicação de empreendimentos dessa natureza. Coriolano e Almeida (2007) pontuam que, até meados do século XX, a região costeira nordestina não era priorizada como espaço urbano capaz de comportar iniciativas voltadas ao turismo. Naquele período, apenas atividades portuárias e de pesca artesanal eram empreendidas, além de ocupações de residências e outras atividades socialmente marginalizadas, como a boemia, artesanato e cultura popular, identificam os autores. Após 1980, o revés foi sentido através da valorização litorânea e financiamento de diversos projetos liderados pelas agências multilaterais de crédito. Coriolano e Almeida (2007) ressaltam que, desde então, existe uma acirrada disputa envolvendo

\footnotetext{
${ }^{9}$ Meio de hospedagem que prevê configurações espaciais elitizadas, localizados, de preferência, em áreas naturais preservadas, distantes dos territórios mais urbanizados. Dependências amplamente preparadas para entreter, oferecer consumo dos mais diversos, sem que os turistas, de alto poder aquisitivo, sintam a necessidade de buscar atividades externas.
} 
Mercados turísticos e desenvolvimento regional: a atuação dos agentes estatais de mercado na economia do turismo no Brasil.

a população litorânea pelos territórios estruturalmente organizados para comportar o turismo, com áreas residenciais e também para atividades econômicas, recreativas e esportivas. Muito se deve ao perfil desenvolvimentista do PRODETUR que, a partir de 1995, ofereceu condições propícias para a ocupação turística do Nordeste, com o marketing, infraestrutura e atração de empresas, sobretudo da rede hoteleira, como os resorts.

Segundo informa Paiva (2014), a partir de dados de 2008, o espaço nordestino estava ocupado por 42 resorts, dos quais se destacam: Salinas de Maragogi e Venta Club Pratigy (Alagoas); Arraial d'Ajuda, Eco Resort, Cana Brava, Catnossaba, Club Med Itaparica, Club Med Trancoso, Itacaré Eco Resort, Kiroa, Costa do Sauípe, Patachocas, Praia do Fort, Renaissance, Super Club, Tororomba, Hotel Transamérica e Txai Resort (Bahia); Hotel Oásis Atlântico, Becha Park e Vila Galé (Ceará); Eco Resort do Cabo, Summervile e Venta Club Porto de Galinhas (Pernambuco); e Pestana (Rio Grande do Norte). Com uma propagação especial ao "resort litorâneo", o Estado da Bahia foi o grande contemplado. Cruz (2005) ressalta que, entre os 25 maiores hotéis construídos e/ou em construção em 2003, 10 estavam na Bahia. Não é para menos, já que, segundo informações de 2006 do Ministério do Turismo, é o Nordeste a região mais promissora para ampliação de investimentos, com $38 \%$, em seguida estão Norte $(27 \%)$, Sul $(13,3 \%)$, Centro Oeste $(11,7 \%)$ e Sudeste (10\%). Justificando essa hierarquização do Estado em relação aos outros destinos nordestinos, Cruz (2005) percorre alguns fatos que valem ser apontados: a Bahia, por si, possui um longo histórico no que se refere a organização e de investimentos públicos no setor; politicamente, é um Estado forte, com inteiras condições de captar recursos para empreendimentos que garantem o retorno dos investimentos e, por fim; o Estado também é procurado por sua localização geográfica sendo, no Nordeste, o mais próximo dos grandes polos emissores de turistas do país (São Paulo e Rio de Janeiro). (CRUZ, 2005). Ademais, a Bahia é o Estado que possui maior extensão costeira do país, concentrando ainda um número elevado de médios e pequenos municípios no seu vasto litoral. Com o fator de organização favorável, se destacam neste Estado alguns roteiros, como: Lagos de São Francisco; Costa dos Coqueiros; Bahia de Todos os Santos; Costa do Dendê; Costa do Cacau; Costa do Descobrimento; Costa das Baleias; Caminhos do Oeste; Chapada Diamantina e Vale do Jequiriçá. 
Em Alagoas, segundo dados divulgados pelo Plano Estratégico de Desenvolvimento do Turismo, que cita o documento Censo Hoteleiro (SETUR, 2011), o perfil de sua hotelaria é relativamente jovem, onde $60 \%$ dos hotéis possuem até dez anos de existência e $40 \%$ possuem mais de dez anos de operação. Ainda, informa, a implantação de novos hotéis nos últimos anos pelo setor privado, tanto em Maceió como em outras regiões turísticas, foi de 18 unidades hoteleiras, com um total de 10.586 UHs. Em 2011, do total de 392 meios de hospedagem, com 10.684 UHs e 27.655 leitos, 26,2\% estavam localizados em Maceió e 73,8\% localizados no interior do Estado, contendo a região Costa dos Corais 23\% dos empreendimentos hoteleiros e a região Lagoas e Mares do Sul, 22\%. No mesmo ano, 22 meios de hospedagem (18 deles localizados em Maceió) se enquadraram em empreendimentos de grande porte, sendo $265(65,2 \%)$ enquadrados sob a tipologia "pousadas".

Políticas turísticas federais e os marcos regulatórios: a pedagogia institucional do novo empreendedorismo e a ética da competição.

A segunda frente de interpenetração entre Estado e mercados turísticos revela a relevância dos agentes estatais, nomeados aqui de agentes estatais de mercado - AEM. Nesta frente as ações dos AEM são mais sutis e complexas, mas não menos decisivas. Por meio de planos estruturadores de médio e longo prazo, dos marcos regulatórios e dos projetos estruturantes, tais agentes realizam uma espécie de pedagogia do novo empreendedorismo e da disseminação da ética da competitividade entre os próprios agentes estatais regionais (Estados) e locais (municípios). Por meio do Plano Nacional de Turismo (PNT) e das ações derivadas da sua matriz estratégica, o governo federal, notadamente a partir de 2006, lança uma interpelação que podemos cunhar de racionalização teóricolegal-conceitual dos espaços, enfatizando as eventuais potencialidades e imprimindo um chamamento geral, algo como: Estados e municípios, “turistifiquem-se"! É dentro dessa racionalização teórico-conceitual-legal que muitas estruturas das administrações públicas do turismo renovaram suas organizações e atribuição de funções, renomeando setores e criando novas competências, como, por exemplo, escritórios de negócios, setores que levam a palavra produto no nome e divisões voltada à construção do marketing turístico. A criação do ministério do Turismo, no dia $1^{0}$ de 
Mercados turísticos e desenvolvimento regional: a atuação dos agentes estatais de mercado na economia do turismo no Brasil.

janeiro de 2003, por meio da Medida Provisória n⿳⺈ 103, posteriormente convertida na Lei 10.683, de 28 de maio de 2003, foi o gatilho desse complexo e multifacetado processo. Antes da criação de uma unidade ministerial própria, no plano federal, as políticas de fomento ao turismo estavam sob a alçada do Ministério do Esporte e Turismo. Com a criação do Ministério do Turismo (MTUR), concedeu-se um caráter de atuação mais específico para a EMBRATUR (Empresa Brasileira de Turismo), que passou a planejar com maior vigor e sistematização os serviços turísticos, inicialmente na apuração dos dados sobre serviços prestados e, posteriormente a esse levantamento, melhoramento dos mesmos. Todo um novo arranjo foi montado, a partir de grandes investimentos com base na acentuada facilitação de captação de recursos. Com os planos urbanísticoturísticos e o melhoramento do litoral, por exemplo, empreendimentos foram financiados para incremento de seus negócios, vicejando novos mecanismos de oferta dos bens de fruição, prazer e bem estar.

Tabela 1 - Índice de competitividade do turismo nacional. 2008-2011.

\begin{tabular}{|c|c|c|c|c|}
\hline \multirow{2}{*}{ Dimensōes } & \multicolumn{4}{|c|}{ Brasil } \\
\hline & 2008 & 2009 & 2010 & 2011 \\
\hline Infraestrutura Geral & 63,8 & 64,6 & 65,8 & 68,4 \\
\hline Acesso & 55,6 & 58,1 & 60,5 & 61,8 \\
\hline Serviços e Equipamentos Turísticos & 44,8 & 46,8 & 50,8 & 52,0 \\
\hline Atrativos Turísticos & 58,2 & 59,5 & 60,5 & 62,0 \\
\hline Marketing e Promoçāo de Destino & 38,2 & 41,1 & 42,7 & 45,6 \\
\hline Politicas Públicas & 50,8 & 53,7 & 55,2 & 56,1 \\
\hline Cooperaçāo Regional & 44,1 & 48,1 & 51,1 & 49,9 \\
\hline Monitoramento & 35,4 & 34,5 & 35,3 & 36,7 \\
\hline Economia Local & 56,6 & 57,1 & 59,5 & 60,8 \\
\hline Capacidade Empresarial & 51,3 & 55,7 & 57,0 & 59,3 \\
\hline Aspectos Sociais & 57,2 & 57,4 & 58,4 & 59,1 \\
\hline Aspectos Ambientais & 58,9 & 61,8 & 65,6 & 67,2 \\
\hline Aspectos Culturais & 54,6 & 54,6 & 55,9 & 57,5 \\
\hline Total Geral & 52,1 & 54,0 & 56,0 & 57,5 \\
\hline
\end{tabular}

Fonte: MTUR/FGV/SEBRAE (2011).

Essa política estratégica iniciada pelo Ministério do Turismo em 2003 também conta com táticas para a aproximação com as 27 Unidades 
Federativas do país. Logo, para colher resultados sobre os níveis de competitividade do turismo brasileiro, é preciso que as regiões tenham condições propícias para disputar seus espaços no mercado. Percebendo a necessidade de estreitar as relações e facilitar a interlocução com diferentes localidades de uma área tão extensa como o território brasileiro, o MTUR cria e dá fôlego ao chamado Plano de Regionalização. A regionalização, indicada como um dos pontos fortes do Plano Nacional de Turismo, é resultado de um planejamento que visa ser descentralizado e compartilhado. Assim, a regionalização é um importante instrumento que organiza as regiões, de acordo com suas potencialidades turísticas, e fazemnas seguir determinadas etapas para recepção dos turistas, seja de serviços qualificados, infraestrutura, construção do destino, etc., capazes de incluílas no mercado competitivo. A proposta põe em formação um mapa turístico que, de 2003 até 2012 conta com 3.635 municípios, organizados em 276 regiões turísticas. (Plano Nacional de Turismo, 2013-2016).

Essa referência na mensuração de competitividade foi construída de 2007 a 2011, quando o Ministério do Turismo, em parceria com o SEBRAE e a Fundação Getúlio Vargas, desenvolveu uma minuciosa pesquisa para identificar possíveis destinos e regiões que fomentavam o turismo, com base, claro, nos critérios de competitividade estabelecidos. A partir dessa metodologia, foram definidos 65 destinos turísticos, dos quais é possível aplicar uma avaliação de seus índices de competitividade. A tarefa, extremamente complexa, faz parte de uma estratégia para identificar nos destinos turísticos em construção, por exemplo, seus níveis de desenvolvimento, acertos, entraves e desafios. Os Estados utilizam a matriz de orientação do Ministério para definir quais os destinos turísticos municipais estão prontos, quais os que precisam se desenvolver e quais os destinos que ainda estão longe de atingir um nível significativo no mercado de competição.

Numa apreensão geral, o Plano identifica algumas metas que são prioridades de sua intervenção até 2016: aumentar para 7,9 milhões a chegada de turistas estrangeiros ao país; aumentar para $\mathrm{R} \$ 10,8$ bilhões a receita do país com o turismo internacional; aumentar para 250 milhões o número de viagens domésticas realizadas; elevar para 70 pontos o índice médio de competitividade turística nacional; aumentar para 3,6 milhões as ocupações formais no setor, que pode ser corroborado a partir do impulso econômico causado pelos megaeventos, sendo um crescimento anual de 
Mercados turísticos e desenvolvimento regional: a atuação dos agentes estatais de mercado na economia do turismo no Brasil.

$6,64 \%$, onde se destacam também o número de empreendedores individuais; apoiar, de maneira mais efetiva, o desenvolvimento das regiões turísticas brasileiras, através da estruturação dos municípios e Estados brasileiros, qualificando a oferta turística, desenvolvendo a economia e aumentando a geração de emprego; melhoria de infraestrutura, como a sinalização e acessibilidade aos destinos e Centros de Atendimento aos Turistas, e também definição de modelos de infraestrutura para as Organizações Públicas de Turismo (OPT); maior rigor, capacitação e monitoramento para aplicação do cadastro unificado aos prestadores de serviços turísticos, cumprindo assim a Lei nº̂11.771/2008, além de promoção da importância sobre a legalização e qualificação no setor; aumentar o volume de investimentos privados no setor; investimentos em campanhas publicitárias para a promoção do turismo interno, enfrentando assim os períodos de baixa ocupação hoteleira e consolidando o Brasil como destino seguro, qualificado, diversificado e sustentável, contribuindo para a diminuição das desigualdades regionais (seguindo as diretrizes do Programa de Regionalização do Turismo); aumento nas ações para incentivo ao associativismo, cooperativismo e empreendedorismo; ações para o fortalecimento do turismo internacional, dentre outros.

O Plano Nacional de Turismo possui uma delimitação muito específica, um conjunto de apontamentos estatísticos robusto e objetivos diretos e ousados para uma economia turística que antes dos anos 2000 sequer possuía um ministério capaz de reconfigurar o processo e desafogar instituições sobrecarregadas. Estamos falando de intenções de explorar bens naturais e culturais para que o país alcance as três primeiras posições mundiais no ranking de países com amplo faturamento com o turismo. $\mathrm{O}$ potencial foi identificado, mas, reconhece o Plano, faz-se necessária uma qualificação de pessoal técnico e incorporação intensa na mensuração dos dados, além de parcerias com institutos de pesquisa já renomados, como destacou Sanovicz (2007). Para aplicação do Plano Nacional de Turismo e alcance de suas missões a longo prazo e planejamento do setor de forma profissional é indiscutível a existência de um padrão de pesquisa e constante atualização dos dados. Para alavancar o setor é preciso conhecêlo. Ainda: a aplicação satisfatória do Plano, com base nas diretrizes e orientações estabelecidas, impulsionaria a Agenda Estratégica do Turismo Brasileiro, capaz de pensar o planejamento do setor num intervalo de 10 
anos. Seria o momento propício ao turismo brasileiro para implementar o Sistema de Informações Turísticas.

Por fim, o mais recente Plano, previsto para atuação até 2016, busca normatizar um sistema de monitoramento que se encarregue de apresentar as informações necessárias sobre políticas disseminadas e resultados atingidos de acordo com as diretrizes do governo, principalmente aos órgãos colegiados que fazem parte do Sistema Nacional de Turismo, ao Conselho Nacional de Turismo (CNT), ao Fórum Nacional de Secretários e Dirigentes Estaduais de Turismo (FORNATUR) e também ao Comitê Interministerial de Facilitação Turística (CIFAT). Entre esses aspectos, a perspectiva de desenvolvimento está intimamente ligada à possibilidade da criação de uma Conta Satélite do Turismo (CST), processo que tramita nas principais vias de discussão do segmento. A CST é um arranjo complexo que visa a contribuição com a mensuração da importância do setor turístico para a economia dos países, e vem sendo fortemente requisitada pela Organização Mundial do Turismo (OMT) e outros órgãos como um indispensável instrumento de gestão, planejamento e estratégia, despertando, a partir dos dados apresentados, condições propícias para a criação de planos de crescimento.

É nessa frente da configuração Estado/mercado turístico que ocorrem as maiores antinomias entre os agentes estatais de mercado (AEM) e os agentes privados de mercado (APM). Diferente das duas outras frentes, a acomodação dos interesses desses agentes é mais difícil e tensa. Na elaboração dos grandes planos nacionais (como o Plano Nacional de Turismo) e na aprovação das normas e legislações do setor, as discussões, estratégias e decisões são realizadas nos circuitos dos profissionais das decisões (políticos profissionais e grupos de interesse partidários) e das elites técnicas governamentais, incorporando pouco os interesses dos empresários, das redes de comerciantes locais e das associações sindicais. O Plano Nacional de Turismo, as Cartilhas de Regionalização, a Conta Satélite do Turismo (CST), entre diversas outras ações de normatização, constituem uma poderosa pedagogia político-institucional, que se espraiou pelos territórios e os seus processos de turistificação. A partir de 2003, torna-se, cada vez mais, comum o uso e a incorporação oficial de termos, noções e categorias como negócios, produtos, índices de competitividade, empreendedorismo e inovação no âmbito das políticas de turismo. Tudo isso combinado às noções de diversidade cultural, cultura local e 
Mercados turísticos e desenvolvimento regional: a atuação dos agentes estatais de mercado na economia do turismo no Brasil.

sustentabilidade. Tais termos foram incorporados às estruturas organizacionais e administrativas dos governos estaduais, municipais e, sobretudo, passaram a definir o novo léxico das políticas federais de turismo.

É com base nesses novos objetivos e buscando disseminar a proposta, dentro de uma reconfigurada ideia de conscientização sobre a importância da organização turística, que, por exemplo, o governo de Alagoas, por meio da SETUR, lança a cartilha com os Critérios de Classificação Turística Municipal. A cartilha é anunciada exatamente como a tradução de uma política pública do Ministério do Turismo ao indicar tomar como parâmetro seus documentos técnico-orientadores, mas facilitando a compreensão dos critérios para que cada município tenha condições reais de trabalhar seus produtos. Fazendo uso de textos de fácil compreensão e figuras ilustrativas, a cartilha promove uma grande reunião de informações que detalham as condições para que os municípios se articulem em regiões turísticas, especificando cada etapa para fins de planejamento e gestão dos locais. Sem perder o foco técnico das orientações de organização, os Critérios de Classificação Turística Municipal alimentam constantemente termos como "sensibilização", "mobilização" e "sustentabilidade", deixando evidente sua proposta pedagógica com relação aos atores envolvidos. Individualmente, não perde de vista a proposta de se enfrentar questões como a informalidade do segmento, dando voz ao Ministério com relação ao cadastro dos prestados de serviços turísticos (CADASTUR), gratuito e obrigatório para: acampamento turístico; agência de turismo; guia de turismo; meio de hospedagem; organizadora de eventos; parque temático e transportadora turística. ${ }^{10}$

Dentre as primeiras orientações aos municípios presente na cartilha, está a organização política dos indivíduos em torno de um bem comum na região. Ou seja, a formação de grupos de discussão, que envolvam atores municipais, públicos e privados, como o exemplo do Conselho Municipal de Turismo (COMTUR) ou o Grupo Gestor, que atua a nível municipal, discutindo e trabalhando ações organizacionais para os destinos, e as Instâncias de Governança, que interferem numa órbita mais ampla, buscando o desenvolvimento de uma região. Os municípios com mais de 21 mil habitantes, com base nas discussões que reúnem os membros da

${ }^{10}$ CADASTUR. Ministério do Turismo. http://www.turismo.gov.br/turismo/home.html 
sociedade organizadamente interessados no desenvolvimento do turismo, devem construir um Plano Diretor, que é uma das principais orientações da cartilha, onde faz-se indispensável no processo de planejamento para a implantação de uma política de desenvolvimento urbano dos locais, com especificações de ações para setores públicos e privados, sancionado através de lei municipal, para nortear atividades de curto, médio e longo prazo, inseridos num planejamento estratégico que preveja oferta e demanda turística, portanto, dando vida a um sistema de informação responsável pela coleta de dados, processo tão requisitado para as administrações turísticas.

Quatro níveis são apresentados pela cartilha e buscam, entre critérios municipais e regionais, pontuar e hierarquizar os municípios com base em seu desenvolvimento. São eles: nível 1 - desenvolver $(0$ a 50 pontos); nível 2 - qualificar para o mercado regional (51 a 70 pontos); nível 3 - qualificar para o mercado nacional (71 a 90 pontos) e, por fim; nível 4 promoção e acesso a mercado (91 a 100 pontos). Todos os níveis especificados na cartilha dos critérios de classificação atendem aos seguintes objetivos identificados: grau de atratividade dos recursos; existência de demanda real; destinos comercializados por agências de turismo; infraestrutura de apoio ao turismo; equipamentos e serviços turísticos; existência de estrutura de gastos turísticos - PPA municipal contemplando o turismo e orçamento direcionado para o setor; organização turística municipal - Secretaria/Departamento/Unidade de Turismo e planejamento turístico (Critérios de Classificação Turística Municipal, Alagoas, 2013). Os municípios devem se debruçar com atenção sobre cada aspecto citado na cartilha e organizar suas informações, afim de construir um banco de dados que ofereça um diagnóstico das condições do seu segmento turístico e enviá-lo ao corpo de profissionais da Secretaria de Estado do Turismo (SETUR) para a averiguação de especialistas e posterior classificação de acordo com os pressupostos formais requeridos pelo Ministério do Turismo (MTUR). 
Mercados turísticos e desenvolvimento regional: a atuação dos agentes estatais de mercado na economia do turismo no Brasil.

A construção dos destinos turísticos: os investimentos publicitários e a mobilização das narrativas de fruição e deleite: peculiaridades do caso alagoano.

A terceira interface estrutural dentro da figuração Estado/mercado diz respeito ao processo de construção dos destinos turísticos. Nessa interface, as ações dos agentes estatais de mercados (AEM), notadamente os governos locais, são decisivas. A construção de um destino culmina naquilo que a linguagem técnico-turística chama de produto. Para a consolidação de um produto turístico, no entanto, é preciso que as duas outras interfaces mencionadas antes estejam mais ou menos consolidadas. Não se trata de uma determinação direta ou uma dependência total, os processos ocorrem de modo sincrônico, mas a construção de um destino/produto não se realiza antes da consecução dos empréstimos (públicos e privados) que permitem a construção dos equipamentos turísticos e das infraestruturas mínimas, assim como exigem um padrão de consenso mínimo da governança dos lugares e territórios acerca das potencialidades e possibilidades reais do turismo, algo que costuma ocorrer mediante a transmissão dos marcos regulatórios, da implementação dos planos estratégicos e, portanto, da incorporação da nova pedagogia institucional do turismo, marcada pelas terminologias de competição, inovação, empreendedorismo, sustentabilidade, diversidade, etc.

Para Paiva (2014), o pensamento do desenvolvimento turístico no Nordeste pode ser delineado a partir de três momentos específicos, que deixam evidentes as formas de atuação estatal, primeiro como planejador e, posteriormente, gerenciador e empreendedor de megaprojetos para o turismo. No primeiro deles, temos a criação da Comissão de Turismo Integrado do Nordeste (CTI/NE) e as primeiras ações do Banco do Nordeste do Brasil (BNB), nascido em 1952, além da já referida SUDENE, até a chegada do II Plano de Desenvolvimento (II PDN). Este último estabelecia a valorização da orla marítima e do patrimônio históricocultural como uma de suas diretrizes mais importantes, ou seja, estabelecendo então o turismo como estratégia viável de desenvolvimento econômico regional. O segundo momento, por sua vez, ficou configurado a partir da emergência em que se fossem implementados em todo o litoral nordestino planos urbanísticos-turísticos. E, por fim, uma terceira fase, marcada por inovações, com o turismo do Nordeste sendo exposto ao 
mundo globalizado e os discursos de desenvolvimento autossustentável, ecológico e cultural sendo alimentados. (PAIVA, 2014).

A constrição especifica dos destinos, particularmente no Nordeste, tomou folego e envergadura particularmente na década dos 90, especialmente a partir das interfaces entre as secretarias estaduais de turismo, o Banco Mundial e o Banco do Nordeste (BNB). Na construção dos destinos e os produtos turísticos os governos locais e estaduais lançam mão de toda sorte de estratégias. Hoje as mais comuns são a compra de espaço de divulgação nos sites de agências de viagens e nas revistas de divulgação das companhias aéreas, bem como a organização de seminários, congressos e eventos junto aos maiores emissores de turistas (nacionais e internacionais) para divulgar os lugares, suas atrações e seus produtos de fruição, deleite e prazer. Elucida-nos Rita de Cássia Ariza Cruz (2005), que, após o redescobrimento do turismo na década de noventa no Brasil, no governo de Collor de Mello, onde a atividade passava a ser vista como refúgio, contra as desigualdades socioeconômicas entre as regiões e, nos anos 2000, da organização do segmento com a criação do Ministério do Turismo, existem ações e políticas que, como a implantação de infraestruturas e preservação de locais históricos, seguem com base em "território usado", categoria de análise cunhada por Milton Santos, em parceria com Maria Laura Silveira, presente no livro "O Brasil - território e sociedade no início do século XXI". O "território usado", explica Cruz (2005), é um sinônimo de espaço geográfico reconhecido e usado pela sociedade e empresas. No entanto, a observação deixa rastros para a compreensão de que existem "territórios não-usados", ou seja, marginalizados, que resguardam heranças da falta de intervenção por meio das políticas. É ancorado nessa distinção do "território usado" e no "nãousado", que muitos autores assinalam que há uma intensa mercadologização do território. "Também aqui o território é reduzido a 'um produto' mal acabado, cuja transformação em mercadoria passível de competição no mercado internacional de 'produtos' (lugares) turísticos requer a intervenção do Estado" (CRUZ, 2005, p.34-35).

O caso alagoano é emblemático acerca da escolha dos territórios usados e não usados. Em janeiro de 2015, a movimentação no Aeroporto Internacional Zumbi dos Palmares apresentou uma elevação superior a $16 \%$, se comparado ao mesmo período em 2014. Segundo dados divulgados pela Empresa Brasileira de Infraestrutura Aeroportuária 
Mercados turísticos e desenvolvimento regional: a atuação dos agentes estatais de mercado na economia do turismo no Brasil.

(INFRAERO), entre voos nacionais e internacionais, totalizaram-se 239.377 passageiros que embarcaram e desembarcaram em território alagoano. Houve o registro de 1.102 pousos e 1.113 decolagens, totalizando 125.026 e 113.402 de passageiros embarcando e desembarcando, respectivamente. Só a empresa Gol Linhas Aéreas Inteligentes foi responsável pela mobilização de 103 mil passageiros pela capital do Estado, com voos saindo direto de Belo Horizonte, Brasília, Porto Alegre, Campinas, Uberlândia, Curitiba e Goiânia. O crescimento se explica em decorrência das últimas negociações envolvendo o potencial turístico do Estado. Segundo matéria publicada pelo Jornal de Alagoas ${ }^{11}$, veiculada em novembro de 2014, o Festival de Turismo de Gramado (FESTURIS), que recebeu 14 mil visitantes nesta edição, trouxe importantes resultados para o Estado de Alagoas, que a partir de $1^{\underline{0}}$ de dezembro de 2014 até 28 de fevereiro de 2015 receberia novas rotas de viagens aéreas diárias pela companhia Gol. O presidente da Associação Brasileira da Indústria de Hotéis (ABIH - AL), Maurinho Vasconcelos, também se manifestou: "Nossa temporada de verão é sempre boa e com anúncios destes novos voos para Maceió, vamos ultrapassar a taxa de $90 \%$ de ocupações. Estes voos da Gol também vão fortalecer o nome de Alagoas nos principais mercados brasileiros" (Jornal de Alagoas, 11 de novembro de 2014).

Segundo os dados da Gerência de Estudos e Pesquisas da SETUR, a capital recebeu aproximadamente 1,8 milhões de visitantes apenas em 2013. A estimativa é que 2,8 milhões de turistas visitaram Alagoas no mesmo ano. Nos onze anos entre 2002 e 2013, houve um aumento de $116 \%$ no fluxo de visitantes global do Estado. A estruturação de diferentes setores do segmento do turismo pode alavancar as estatísticas. Por exemplo, a capital Maceió vem se consolidando no segmento de cruzeiros marítimos, movimentando cerca de 59 navios atracados e 120 mil passageiros que desembarcaram, entre os anos de 2009 e 2010. Nas temporadas de 2010 e 2011, a movimentação foi de 60 navios, com 113 mil passageiros e, nas temporadas de $2011^{12}$ e 2012, a

${ }^{11}$ Portal Jornal de Alagoas. http://www.jornaldealagoas.com.br/

12 Segundo o Plano Estratégico de Desenvolvimento do Turismo, o ano de 2011 foi aquele em que o governo de Alagoas, por meio da SETUR, investiu no Terminal Turístico no porto de Maceió, com vistas ao fortalecimento desse setor econômico. A ação também tem parceria com a Secretaria Municipal de Promoção do Turismo em Maceió (Plano Estratégico de Desenvolvimento do Turismo, 2013). 
movimentação foi de 49 navios e 112 mil passageiros. A diminuição nos números pode ser atribuída aos impactos provocados pela crise na Europa.

Tabela 2 - Comparativo anual do fluxo de visitantes - 2002/2013.

\begin{tabular}{c|ccccccccccccc} 
& 2002 & 2003 & 2004 & 2005 & 2006 & 2007 & 2008 & 2009 & 2010 & 2011 & 2012 & 2013 \\
$\begin{array}{c}\text { Fluxo } \\
\text { global de } \\
\text { visitante } \\
\text { Maceión }\end{array}$ & 889.622 & 1.012 .618 & 951.922 & 1.100 .780 & 1.068421 & 1.014 .167 & 1.099 .795 & 1.284 .815 & 1.346 .933 & 1.501 .005 & 1.595 .518 & 1.801 .700 \\
\hline $\begin{array}{c}\text { Fluxo } \\
\text { global de } \\
\text { visitantes } \\
\text { Alagoas }\end{array}$ & 1.334 .433 & 1.518 .927 & 1.427 .883 & 1651.170 & 1.602 .632 & 1.521 .251 & 1.649 .693 & 1.927 .222 & 2.020 .400 & 2.401 .608 & 2.552 .829 & 2.882 .720
\end{tabular}

Fonte: Gerência de Estudos e Pesquisas - SETUR/AL.

Importante ressaltar que a boa média estabelecida pela capital alagoana em relação ao fluxo de visitantes alterou sua posição entre os destinos mais visitados pelos turistas nacionais. Segundo os indicadores da Caracterização e Dimensionamento do Turismo Doméstico no Brasil, Maceió não estava nem entre os 30 destinos mais visitados por turistas nacionais. Com a atualização das estatísticas, a capital passou a ocupar, em 2011, a $16^{\text {a }}$ posição, mantendo também a $13^{\underline{a}}$ posição com relação as 20 cidades mais desejadas para visitação pelos turistas, onde também compõe a lista: Fernando de Noronha, Natal, Florianópolis, Manaus, Gramado, Porto Alegre e Bonito. O crescimento de visitação é um dos dados mais trabalhados para justificar a necessidade de uma organização com qualidade. Ainda segundo os dados fornecidos pelo governo de Alagoas, só em 2011, Maceió recebeu aproximadamente 600 mil hóspedes, com recorde para o mês de janeiro que, sozinho, alcançou a marca de $68 \mathrm{mil}$ hóspedes. Nesse ano, todos os meses apresentaram melhora se comparados aos meses do ano anterior. O próprio mercado regional e o do Sudeste são as maiores procedências no fluxo de turistas. Já com relação a procedência do fluxo de turistas internacionais, segundo dados fornecidos pela SETUR, em 2011, os maiores fluxos de visitantes eram provenientes de países da 
Mercados turísticos e desenvolvimento regional: a atuação dos agentes estatais de mercado na economia do turismo no Brasil.

América do Sul (59,8\%), liderados pela Argentina (43\%) e Europa (59,8\%), liderados por Portugal (12\%).

A oportunidade de novas rotas pressupõe uma atenção redobrada ao estruturamento do destino para receber a ampla demanda. Ao longo da renovação da Secretaria de Estado do Turismo (SETUR) algumas ações têm sido priorizadas, para alcançar resultados ainda mais expressivos, não apenas na chegada, mas permanência do turista, num ambiente que seja capaz de atender as suas necessidades. Algumas práticas, nesse sentido, se destacam, como o caso do Projeto de Dinamização e Sustentabilidade do Turismo no Baixo São Francisco, que busca atuar com base na formação das comunidades ribeirinhas a partir, dentre várias ações, investidas no ramo empresarial, para que cada empresário tenha conhecimento dos produtos ofertados na região, com vistas a formar uma rede de cooperação, que seja capaz de indicar destinos e produtos aos turistas visitantes, além da conscientização para a exploração sustentável do turismo ${ }^{13}$. O projeto, além do preparo da região, é mais uma iniciativa para desobstruir o aglomerado de turistas que preferem o turismo de sol e praia, o que ainda impõe limitações às vagas e condições de hospedagens de redes e hotéis limítrofes.

Além do trabalho em torno da confecção de folders, o projeto lançou recentemente uma plataforma online ${ }^{14}$ com inúmeras informações sobre sua composição da proposta e dos 12 municípios envolvidos, desde histórias dos locais, alimentação e opções de hospedagem. O portal informativo também publica fotos e vídeos sobre os locais onde o projeto sustentável é aplicado, dividindo sua concentração em cinco áreas: caminhos do artesanato; caminhos da história; caminhos da gastronomia; caminhos da aventura e caminhos da natureza. Outros mecanismos interativos e narrativos também foram pensados para disseminar o projeto na sociedade alagoana, a exemplo de um aplicativo para smartphones, que pode ser baixado de forma gratuita através de aparelhos com sistemas Android ou IOS, além das já requisitadas redes sociais, como Facebook e

\footnotetext{
${ }^{13}$ No início do projeto, relata a equipe de gestão, foi realizado um zoneamento turístico do Baixo São Francisco, onde puderam ser identificados todos os biomas e especificidades naturais. Com o zoneamento, foram formuladas proposições de zonas de conservação.

${ }^{14}$ Portal Caminhos do São Francisco. http://caminhosdosaofrancisco.com.br/
} 
Instagram. Ao portal PANROTAS ${ }^{15}$, a secretária de Estado do Turismo disse: "As redes sociais são grandes vitrines para o destino, pois são canais que auxiliam nas vendas do produto turístico e isso ajuda no fortalecimento do turismo local, já que são compartilhadas imagens e também experiências" (Danielle Novis, entrevista ao Portal PANROTAS, 2014).

Foi dentro desse contexto e possibilidades de construção de novos destinos e seus respectivos produtos, que a SETUR-AL passou a se concentrar em uma fase específica na organização dos produtos, fazendo o mapeamento de todo o Estado de Alagoas para identificar os elementos e possibilidades de segmentação que poderiam ser melhor trabalhados. Daí resultou, por exemplo, o turismo de aventura, preparado em parceria com a Associação Brasileira de Turismo de Aventura (ABETA). Mais tarde, a SETUR, através do governo de Alagoas, também investiu no mapeamento e identificação cultural das cidades históricas, como Marechal Deodoro, Penedo e Piranhas, sendo aportado recurso pelo Ministério da Cultura, o que resultou no tombamento das três cidades como patrimônio da humanidade, pelo Instituto de Patrimônio Histórico e Artístico Nacional (IPHAN). A cidade de Piranhas, por exemplo, localizada às margens do Rio São Francisco, a 280 km de Maceió e com pouco mais de 20 mil habitantes, tem se destacado amplamente através da conservação de seu Centro Histórico, oferecendo monumentos e bens arquitetônicos como o Relógio da Torre, a Estação Ferroviária, além de inúmeros prédios históricos, como museus e o Galpão da Feirinha e do artesanato. A cidade tem se consolidado como um dos novos produtos turístico-culturais no âmbito do destino Baixo São Francisco. Esses aspectos estão conjugados à formação dos produtos ligados ao incentivo da experiência de aventura e da aventura ecológica ou ambiental vicejada pela região.

${ }_{15}$ Portal PANROTAS. http://www.panrotas.com.br/ 
Mercados turísticos e desenvolvimento regional: a atuação dos agentes estatais de mercado na economia do turismo no Brasil.

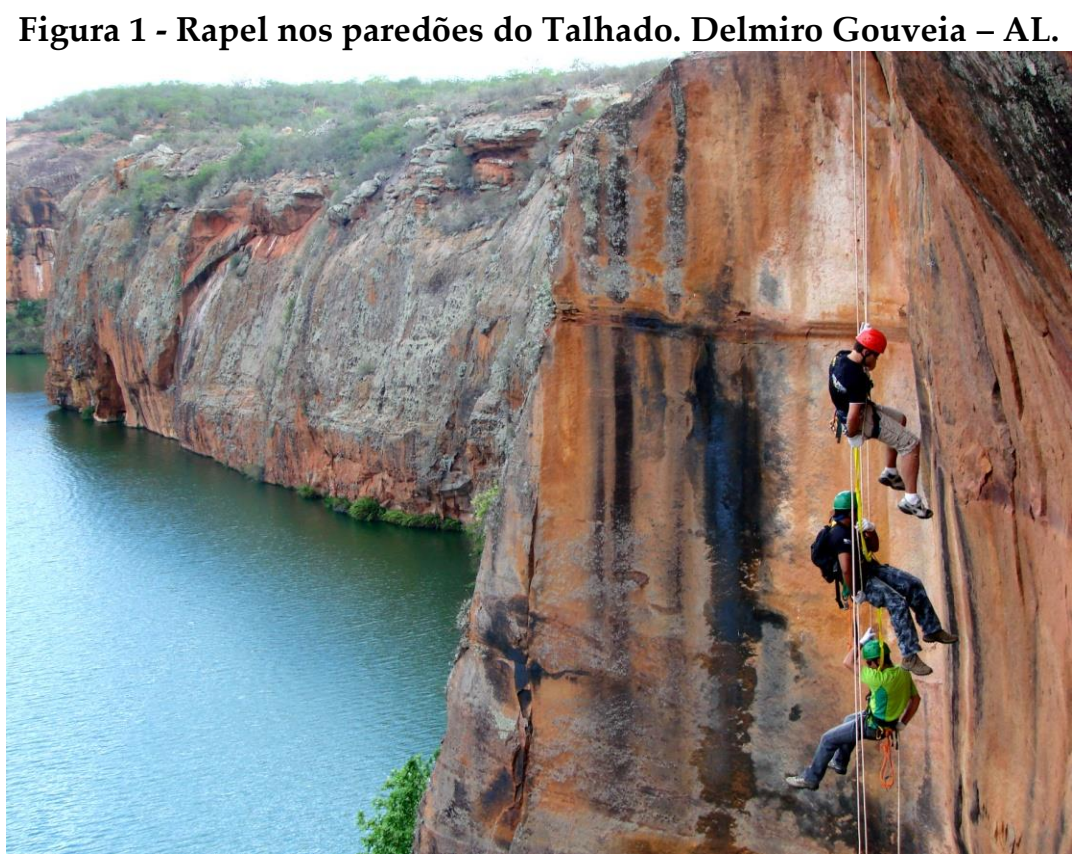

Fonte: Portal Caminhos do São Francisco. http://caminhosdosaofrancisco.com.br/

Não se constrói e se consolida um destino turístico e os produtos a ele associado da noite para o dia. São necessárias as condições sociais de possibilidade e a existência de um arco de processos sociológicos mais amplos. A própria ideia da segmentação turística e toda a sua implementação exige estudos prévios e um conhecimento acurado dos contingentes e perfis de turistas. Estes estudos costumam ser encomendados pelas governanças locais (segunda frente de interface) a universidades, centros de pesquisa e institutos de pesquisa. Como outros estados e regiões do Brasil, Alagoas tem buscado diversificar os seus destinos, envidando esforços políticos, institucionais e econômicos para consolidar o destino sol e mar, mas, ao mesmo tempo, lançando outras possibilidades. Uma delas tem sido a cristalização do destino Baixo São Francisco. No caso de Alagoas, a construção dos destinos no território do Estado, torando-os usados e "mercadologizados", enfrenta severas dificuldades. Para lograr a eficácia pretendida, o processo de construção dos destinos necessita contar com a intensa participação da governança local (segundo eixo de interfaces) e da mobilização das competências criativas e empresariais dos agentes privados de mercado (primeiro eixo de interfaces), que não podem prescindir dos recursos humanos e das 
capacidades técnicas disponíveis nos locais. Em um Estado com os mais baixos índices socioeconômicos do país e uma das maiores desigualdades de renda e acesso aos serviços públicos, a exemplo do menor índice de Desenvolvimento Humano (IDH) do Brasil, com 0,677, a maior taxa de analfabetismo do país, atualmente com $24,6 \%$, e o analfabetismo funcional, com 36,5\%, fica bastante difícil "mercadologizar" os seus territórios. Por isso, nos polos localizados nas regiões Lagoas e Mares do Sul e Costa dos Corais foi identificado e realizado um alto número de cursos, workshops, missões técnicas, consultorias, direcionados aos empresários, artesãos e comerciantes em geral no âmbito dos Programas de Arranjos Produtivos Locais (PAPLs) dessas regiões. Mesmo assim, ainda é um sistema de capacitação funcional para o turismo que encontra grandes dificuldades para se desenvolver, por se deparar com os baixos níveis de escolaridade e a reduzida capacidade de mobilização das competências criativas e empreendedoras.

O caso alagoano demonstra como, durante os últimos 15 anos, os sucessivos governos estaduais têm buscado realizar uma tradução mediada das políticas nacionais de turismo, notadamente a partir de 2003, ano da criação do MTUR e da intensificação dos planos institucionais responsáveis, entre outros aspectos e agentes, pela mercadologização dos territórios. Em Alagoas, a tradução mediada dessas políticas nacionais atingiu seu ápice através da elaboração e implantação do Plano Estratégico de Desenvolvimento do Turismo, documento com força de lei e planejado para orientar o Estado num intervalo de dez anos, que vai de 2013 até 2023 (com elaboração de atualizações prevista). Como indica introdutoriamente o Plano, que se propõe ao combate de uma cultura de informalidade na gestão: a estratégia de desenvolvimento do turismo "deve conduzir a uma nova forma de gestão público-privada, em que diferentes atores desempenham o papel de produtores e articuladores de políticas públicas, desde o desenho até a implementação e acompanhamento das ações" (JORDAN, 2009). Como parte da estruturação regional, o Plano prevê a utilização dos bens históricos que já fazem parte das características alagoanas como promoção. É o caso do turismo étnico expresso, por exemplo, através do Roteiro Integrado da Civilização do Açúcar que, assim como a Região dos Quilombos, busca a valorização de um aspecto ainda marcante para o Estado, como a cultura da plantação da cana-de-açúcar. Segundo o Plano, o roteiro é resultado do projeto Rede de Cooperação 
Mercados turísticos e desenvolvimento regional: a atuação dos agentes estatais de mercado na economia do turismo no Brasil.

Técnicas para Roteirização, uma realização do Ministério do Turismo em parceria com o SEBRAE e o Instituto Marca Brasil. A proposta é criar um produto diferenciado, destacando uma rota simbólica compartilhada que integrem municípios e os Estados de Alagoas, Paraíba e Pernambuco. No entanto, o projeto ainda encontra-se numa etapa inicial de desenvolvimento e se depara com inúmeras dificuldades pois, ainda sendo uma característica presente na economia do Estado, a visitação aos engenhos perpassa a liberação dos proprietários, pois muitos destes encontram-se em terrenos particulares. Além disso, é citado a resistência e a dificuldade no firmamento de parcerias entre setores públicos e privados do Estado, para a construção de uma rota turística segura e fiel ao programa proposto.

O Plano Estratégico de Desenvolvimento do Turismo (PEDT), documento com força de lei, pretende reforçar e incrementar os critérios utilizados pela Secretaria de Estado do Turismo (SETUR) que, desde 2012, desenvolveu seu próprio sistema de classificação dos municípios alagoanos, de acordo com seus estágios de evolução turística, identificando aspectos naturais, culturais, históricos, artesanais, manifestações populares, dentre outros. Como anteriormente citado, regiões como a Metropolitana, Caminhos do São Francisco, Costa dos Corais, Lagoas e Mares do Sul e Quilombos já tiveram seus potenciais reconhecidos e são prioridades de ação. O Plano é um documento que programa uma ampla variedade de projetos a serem implantados. No escopo do Plano, estão listados projetos como remapeamento dos municípios turísticos, o projeto de consolidação do programa de municipalização do turismo no Estado, o projeto de estruturação e institucionalização de instâncias de governança regionais, projeto de inventariação da oferta turística, projeto de apoio à estruturação dos atrativos turísticos, programa de qualificação dos produtos turísticos, capacitação profissional, empresarial, educação para o turismo e ambiental, diversificação e competitividade da oferta turística, organização comunitária, normalização e certificação, promoção, marketing e comunicação, fortalecimentos da promoção por meio do turismo de negócios e eventos, dentre outros muito módulos previstos.

\section{Considerações finais}

O fio condutor deste trabalho foi tecido pelo propósito de evidenciar a trama de interfaces envolvendo a figuração Estado/mercados 
turísticos no Brasil. Um dos elementos centrais e constitutivos dessa figuração (ELIAS, 1992) diz respeito às ações dos diversos agentes estatais de mercado (AEM). No entanto, ao cunhar essa categoria e buscar torná-la operacional e útil à compreensão da economia do turismo no Brasil, não sustentamos qualquer pretensão de defender um suposto "super Estado" ou algo similar. Nem tampouco sugerimos que existe, de fato, um estado que faz tudo, decide e cria. Longe disso. Sabemos que as políticas turísticas, os financiamentos públicos e os investimentos simbólico-materiais levados a termos para a construção dos destinos são objeto de disputas permanentes, envolvem os interesses corporativos, empresariais, setoriais e políticos dos mais variados agentes privados (notadamente as empresas). Todavia, sugerimos que o Estado e as estruturas governamentais são mais complexos e multifacetados do que se imagina; são muito mais redes diferenciadas e tensionadas e muito menos unidades monolíticas homogêneas. Por isso, para capturar como as economias da imaterialidade funcionam e são dinamizadas, como é o caso da economia do turismo, é preciso dilatar a categoria empírica e conceitual de mercado, tornando-a mais ampla, menos reificada, normativa e restrita. A grande maioria dos mercados, especialmente os mercados turísticos, simplesmente não existiriam sem os agentes estatais de mercado (AEM), que são integrados pelos governos e as diversas instituições estatais oficiais, como bancos, ministérios, secretarias, prefeituras, institutos de pesquisa, empresas públicas, instituições de treinamento e capacitação (como o sistema S), órgãos de apoio e desenvolvimento, entre outros.

\section{Referências}

ALAGOAS, Secretaria de Estado do Turismo de Alagoas. Cartilha de Regionalização. Regionalização e Critérios de Classificação dos Municípios Turísticos de Alagoas. Maceió, 2011.30p.

Indicadores do Turismo em Alagoas.

Maceió. fev. 2013a. 28p.

Plano Estratégico de Desenvolvimento

do Turismo 2013-2023. Maceió. 2013b, 92p.

Programa de Municipalização e

Regionalização do Turismo: critérios de classificação turística municipal. Maceió. 2013c, 51p. 
Mercados turísticos e desenvolvimento regional: a atuação dos agentes estatais de mercado na economia do turismo no Brasil.

; Instituto de Assessoria para o Desenvolvimento Humano - IADH. Elaboração do Plano Estratégico de Desenvolvimento do Turismo no Estado de Alagoas. Documento do Plano Estratégico - versão preliminar. Recife. dez. 2012. 209p.

BANCO CENTRAL DO BRASIL, Relatório Anual. Brasília. 2007, 248p. Disponível em:

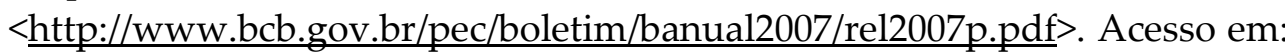
18 dez. 2015.

Brasil é o $6^{\text {o }}$ no mundo em economia do turismo. Portal Brasil. 05 abr. Disponível em: <http://www.brasil.gov.br/turismo/2014/04/brasil-e-o-6ono-mundo-em-economia-do-turismo > . Acesso em: 22 de nov. 2015.

BRASIL, Ministério do Turismo. Estudos da competitividade do turismo brasileiro. Brasília. 2007, 38p.

Disponível Panorama do turismo no mundo 2013.

wh. dadosefatos turismo.gov.br/export/sites/default/da statisticas indicadores/downloads estatisticas/Estatistica e indicadores $\mathrm{T}$ urismo no mundo_2013.pdf $>$. Acesso em: 18 de dez. 2015.

. Plano Nacional de Turismo: diretrizes, metas e programas 2003-2007. Brasília. 2003, 48p.

- Plano Nacional de Turismo: o turismo fazendo

muito mais pelo Brasil 2013-2016. Brasília. 2013, 111p.

BOURDIEU, Pierre. Sobre o Estado. São Paulo: Cia das Letras, 2014.

CORIOLANO, Luzia Neide M. T.; ALMEIDA, Humberto Marinho de. O turismo no Nordeste brasileiro: dos resorts aos núcleos de economia solidária. Revista Electrónica de Geografía y Ciencias Sociales. Barcelona: Universidad de Barcelona, Vol.11, no245 (57), 01 ago. 2007. Disponível em: $<$ http://www.ub.edu/geocrit/sn/sn-24557.htm >. Acesso em: 20 de nov. 2015. CRUZ, Rita de Cássia Ariza da. Políticas públicas de turismo no Brasil: território usado, território negligenciado. Geosul (UFSC), Florianópolis, SC, v.20, n.40, p. 27-43, 2005.

ELIAS, Norbert; DUNNING, Eric. A busca da excitação. Difel, Lisboa. 1992.

Financiamento de banco para turismo tem maior volume no ano, mas abaixo de 2014. Época. 25 set. Disponível em: $<$ http://epoca.globo.com/tempo/expresso/noticia/2015/09/financiamento-de- 
banco-para-turismo-tem-maior-volume-no-ano-mas-abaixo-de-2014.html>. Acesso em: 19 de nov. 2015.

Financiamentos para o turismo somam $R \$ 78,2$ bilhões. Ministério do Turismo. 29 set. Disponível em: <http://www.turismo.gov.br/\%C3\%BAltimasnot $\%$ C3\%ADcias/5542-financiamentos-para-o-turismo-somam-r\$-78,2-

bilh\%C3\%B5es-2.html>. Acesso em: 19 de nov. 2015.

LIPOVETSKY, Gilles; SERROY, Jean. A estetização do mundo: viver na era do capitalismo artista. São Paulo, Editora Companhia das Letras, 2015.

PAIVA, Maria das Graças de Menezes Venâncio. Análise de programas de turismo no Nordeste na perspectiva dos planejamentos participativo e estratégico. Rev. Econ. NE, Fortaleza, v.45, n.1, p. 90-105, jan./mar. 2014.

Piranhas, no Sertão de AL, oferece roteiro turístico histórico e cultural. G1 Alagoas. 09 set. 2013. Disponível em: <http://g1.globo.com/al/alagoas/noticia/2013/09/piranhas-no-sertao-de-aloferece-roteiro-turistico-historico-e-cultural.html>. Acesso em: 18 de dez. 2015.

POCHMANN, Macio. Nova classe média? Boitempo, São Paulo, 2012.

SANOVICZ, Eduardo. A promoção comercial do turismo brasileiro no exterior: o caso da reconstituição da Embratur. 169p. Doutorado em Turismo. Universidade de São Paulo, São Paulo, 2007.

SÃO PAULO, Associação Brasileira das Empresas Aéreas - ABEAR. Dados e Fatos. [20--]. Disponível em: <http://www.abear.com.br/dados-e-fatos>. Acesso em: 19 de dez. 2015.

Setur e Cadastur realizam senso hoteleiro em Alagoas. Alagoas 24 horas. 16 mar. 2011. Disponível em: <http://www.alagoas24horas.com.br/637481/setur-ecadastur-realizam-censo-hoteleiro-em-alagoas/>. Acesso em: $20 \mathrm{de}$ dez. 2015.

SOUZA, Jessé. Os batalhadores brasileiros. Nova classe média ou nova classe trabalhadora? Belo Horizonte, UFMG, 2010.

Temporada de verão de Maceió vai ganhar novos voos. Prefeitura de Maceió. 10 nov. $2014 . \quad$ Disponível em: $<$ http://www.maceio.al.gov.br/semptur/noticias/temporada-de-verao-demaceio-vai-ganhar-novos-voos/>. Acesso em: 20 de nov. 2015.

Trade alagoano participa de Festival de Turismo em Gramado, Agência Alagoas. 07 nov. 2014. Disponível em: $<$ http://agenciaalagoas.al.gov.br/noticias/2014/11/trade-alagoano-participade-festival-de-turismo-em-gramado>. Acesso em: 20 de nov. 2015. 
Mercados turísticos e desenvolvimento regional: a atuação dos agentes estatais de mercado na economia do turismo no Brasil.

URRY, John. O olhar do turista: lazer e viagens nas sociedades contemporâneas. São Paulo, Editora Studio Nobel/SESC, 1996. 